\title{
Association between the Nutritional Quality of Household At-Home Food Purchases and Chronic Diseases and Risk Factors in the United States, 2015
}

\author{
Armen Ghazaryan ${ }^{1, *(D)}$, Andrea Carlson ${ }^{2}$, Alana Y. Rhone ${ }^{2}$ and Kakoli Roy ${ }^{1}$ \\ 1 Office of the Director (OD), National Center for Chronic Disease Prevention and Health \\ Promotion (NCCDPHP), Centers for Disease Control and Prevention (CDC), Atlanta, GA 30341, USA; \\ kjr3@cdc.gov \\ 2 Economic Research Service (ERS), United States Department of Agriculture (USDA), \\ Washington, DC 20024, USA; andrea.carlson@usda.gov (A.C.); alana.y.rhone@usda.gov (A.Y.R.) \\ * Correspondence: armen.ghazaryan@fulbrightmail.org
}

Citation: Ghazaryan, A.; Carlson, A.; Rhone, A.Y.; Roy, K. Association between the Nutritional Quality of Household At-Home Food Purchases and Chronic Diseases and Risk Factors in the United States, 2015. Nutrients 2021, 13, 3260. https:// doi.org/10.3390/nu13093260

Academic Editor: Stefano Erzegovesi

Received: 24 August 2021

Accepted: 16 September 2021

Published: 18 September 2021

Publisher's Note: MDPI stays neutral with regard to jurisdictional claims in published maps and institutional affiliations.

Copyright: This is an open access article, free of all copyright, and may be freely reproduced, distributed, transmitted, modified, built upon, or otherwise used by anyone for any lawful purpose. The work is made available under the Creative Commons $\mathrm{CC} 0$ public domain dedication.

\begin{abstract}
Lower diet quality is a leading preventable risk factor for obesity and chronic diseases. This study assesses differences in the nutritional quality of at-home food purchases, using the Healthy Eating Index (HEI)-2015 and its components, among households with and without a member reporting type 2 diabetes (T2D), cardiovascular disease (CVD), obesity, and/or smoking. We use the 2015 IRI Consumer Network nationally representative household food purchase scanner data, combined with the IRI MedProfiler and the USDA's Purchase-to-Plate Crosswalk datasets. For each/multiple condition(s), the difference in mean HEI score adjusted for covariates is tested for equivalence with the respective score against households without any member with the condition(s). The HEI score is higher for households without a member with reported T2D (2.4\% higher), CVD (3.2\%), obesity $(3.3 \%)$, none of the three conditions $(6.1 \%$, vs. all three conditions), and smoking $(10.5 \%)$ than for those with a member with the respective condition. Households with a member with T2D score better on the added sugar component than those with no member reporting T2D. We found that the average food purchase quality is lower than the recommended levels, especially for households with at least one member reporting a chronic condition(s).
\end{abstract}

Keywords: Healthy Eating Index; type 2 diabetes; cardiovascular disease; obesity; smoking; chronic diseases; scanner data; IRI Consumer Network; IRI MedProfiler

\section{Introduction}

Poor diet is a major preventable risk factor for the leading causes of chronic disease in the United States, including obesity, heart disease, diabetes, hyperlipidemia, and stroke [1]. Although nutrition research has traditionally focused on individual dietary components and food groups, an increasing number of studies illustrate the importance of interactive and cumulative effects of eating patterns and diet quality/healthfulness on health outcomes [1-4]. One such measure of diet quality is the Healthy Eating Index 2015 (HEI2015), which examines the alignment of dietary patterns with the Dietary Guidelines for Americans 2015-2020 [5] (range 0-100, with 100 suggesting full alignment), with previous iterations of the measure-HEI-2005 and HEI-2010 - indicating alignment with the DGA 2005-2010 and DGA 2010-2015, respectively [2].

There is growing literature relating higher HEI scores (among other diet quality measures) to better health outcomes/reduced risk factors, and findings from these studies have been summarized in systematic reviews and meta-analyses [6,7]. To our knowledge, studies analyzing the association between HEI scores and type 2 diabetes (T2D), cardiovascular disease (CVD) incidence and/or mortality, obesity, and smoking status have relied primarily on 24-h dietary recall data [8,9] (e.g., the National Health and Nutrition Examination Survey (NHANES)) and food frequency questionnaire data [10-16]. The advantages and 
limitations of constructing HEI scores based on these data have been discussed in the literature [2]. In addition, most of these studies focused on specific population subgroups, such as women in general [10] and postmenopausal women specifically [11], survey participants from lower-income households in the southern U.S. states [14,15], or participants recruited from certain states and communities $[3,12,13,16]$.

The objective of this study is to analyze the difference in the retail food purchase quality (measured in terms of HEI-2015) by household income and among households with and without a member with reported T2D, CVD, obesity, or smoking. We use nationally representative household food purchase scanner data, which, unlike data from dietary recall and food frequency questionnaires, cover food purchases over an entire year. We try to explore two research questions. First, does retail food purchase quality for at-home consumption improve with household income? Second, do households with member(s) with one or multiple chronic conditions/risk factors purchase lower quality retail food for at-home consumption than those without the given health condition? Even though store food purchases do not necessarily translate into intake, they have been shown to produce similar HEI scores as those calculated based on household food acquisition data, dietary intake, and national food availability data [17]. Focusing on quality of household food purchases instead of individual food intake also allows exploring the role that the household food environment plays in shaping individual dietary intake and health outcomes [18,19], which, in turn, may provide insights for intervention strategies to improve dietary quality.

\section{Materials and Methods}

The IRI Consumer Network Panel (CNP) dataset from 2015 provides information on household retail food purchases. The data are derived from the National Consumer Panel (NCP), which is a joint venture owned by IRI and The Nielsen Company [20]. Third-party vendors providing online advertising (e.g., via display networks, blogs, email, social media, etc.) recruit households for the NCP, who can then sign up on $\mathrm{NCP}^{\prime} \mathrm{s}$ online recruitment site and answer a detailed questionnaire on household demographics [20]. To make the panel representative of the U.S population in the 48 contiguous states, a random sample of households was selected for membership based on quotas for each type of household [20]. More details about household recruitment and selection are provided in the ERS's technical bulletin [20]. Selected households recorded all retail food purchases by scanning each product's bar code throughout the year. Households' race and ethnicity were self-defined and may represent either the primary respondent's characteristics, those of other members of the household, or the entire household's characteristics [20,21]. Using specific thresholds for expenditures based on household size, IRI determines whether a household provides sufficient purchase data and defines them as a static panel of households [20]. We merged the demographic and food purchase data with the IRI MedProfiler 2015, which is a subset of households from the CNP with responses to an annual opt-in survey on health characteristics of household members [20]. All CNP households were offered to participate in the survey and about $52 \%$ of the households in the static panel had at least one person respond to the MedProfiler survey in 2015 (73,490 individual respondents). We focused our analysis only on those households participating in both datasets (CNP and MedProfiler) and used the MedProfiler projection factors (survey weights), which indicate how many households are represented by each participating household in the static panel. IRI assigns projection factors to participating households to match the Census targets by weighting the data based on geographic and demographic characteristics.

Participants in the MedProfiler survey were asked to respond to questions regarding common health characteristics with one of five possible responses: suffer but do not treat, suffer and treat with a prescription, suffer and treat with over-the-counter medication, suffer and treat with both prescription and over-the-counter medications, or do not suffer. Based on this information, we created four binary indicators, which were equal to one for households in which anyone reports suffering from one of the following conditions: congestive heart failure, heart attack, high blood pressure, or stroke (henceforth CVD); 
obesity; T2D; all three conditions combined; and another binary variable indicating whether someone aged 21 or over in the household reported smoking cigarettes.

Next, we combined the merged subsample with the USDA's Purchase-to-Plate Crosswalk (PPC) dataset, which links IRI scanner data with USDA nutrition databases (nutrient and food group quantities) [17]. Quantities for random-weight products (i.e., products purchased by the pound or unit) are not available in the IRI data [20]. Therefore, PPC does not include nutrition information for these products [17]. As a result, households whose reported purchases consisted of only such random-weight products, for which the quantity and nutrition information was missing, were excluded from the analysis. We used the combined data to calculate household HEI-2015 scores after aggregating all reported food purchases over an entire year at the household level. To compare the average HEI scores and the sub-scores, we first stratified the data by household poverty level, following the U.S. Federal Poverty Guidelines for 2015 [22]: (a) at or below 130\% of poverty; (b) between $130 \%$ and $185 \%$ of poverty; and (c) above $185 \%$ of poverty (higher percentage reflecting higher per person household income). The stratification by income was implemented to capture household eligibility for certain programs, such as the Supplemental Nutrition Assistance Program (SNAP) and the National School Lunch Program (NSLP). Then, for each/multiple condition(s)/health behavior(s), the difference in mean HEI score was tested for equivalence with the respective score against households without any member with the condition(s)/behavior(s). We compared the mean HEI scores and its sub-scores adjusted for demographic and socioeconomic factors, such as household poverty level, size, race, and ethnicity; household head's age and marital status; and whether a household is femaleled. We used Stata version 16 (StataCorp LLC, College Station, TX, USA) to perform the analyses and used Stata's SVY commands to account for the complex sampling design and weighting. The results reported are based on the weighted sample.

\section{Results}

\subsection{Household Characteristics}

Household characteristics, both overall and stratified by income levels, are presented in Table 1. The static household panel for which there were enough nutrition data (i.e., households whose reported purchases do not consist of only random-weight products) to construct HEI scores is composed of 63,578 households. In the data used, $15.2 \%$ of the households are at or below the $130 \%$ of poverty (henceforth, income group 1 (IG1)); $8.8 \%$ are between $130 \%$ and $185 \%$ of poverty (income group 2 (IG2)); and $76 \%$ are above $185 \%$ of poverty (income group 3 (IG3)). The average household head's age is 52.5 with an average household size of almost 3 people. The racial/ethnic composition of the primary respondent for the household in the sample is as follows: $76.8 \%$ white, $11.8 \%$ black, $4.3 \%$ Asian, and $7.1 \%$ other; $11.8 \%$ identified as Hispanic. About $61.8 \%$ of households reported having a married household head(s) and $27.5 \%$ having only a female household head. Only female household head means that the household does not have a male household head but it does not necessarily mean that the female is unmarried and/or that it is a single household.

Table 2 presents the percentage of households with a member with one or multiple health outcomes/behaviors. The sample size for households with both health condition/behavior data and enough information to construct HEI scores is 33,179 . In our sample, $14.1 \%, 42.2 \%, 21.5 \%$, and $16.4 \%$ of households have at least one member with reported T2D, CVD, obesity, or smoking, respectively. When stratified by income, the values are higher for households in IG1 and lowest for IG3 for all conditions except for CVD, for which households in IG2 have the highest percent (44.7\%), followed by IG3 (42.3\%) and IG1 $(39.9 \%)$. About $4.5 \%$ of households reported all three conditions (T2D, CVD, and obesity), and $46.6 \%$ of households reported not having any of the three conditions. About $27 \%$ and $22.1 \%$ of households in IG1 and IG2, respectively, have an adult smoker, while among IG3 households the value is $13.5 \%$. 
Table 1. Household characteristics, overall and by poverty level, based on Information Resources Inc. (IRI) Consumer Network 2015 data.

\begin{tabular}{|c|c|c|c|c|c|}
\hline & All Incomes & $\begin{array}{l}\text { Household (HH) } \\
\text { Income < = 130\% } \\
\text { Poverty Income } \\
\text { Group (IG)1 }\end{array}$ & $\begin{array}{c}\text { HH Income } \\
\text { (130-185\%] Poverty } \\
\text { IG2 }\end{array}$ & $\begin{array}{l}\text { HH Income > 185\% } \\
\text { Poverty IG3 }\end{array}$ & $n$ \\
\hline \multirow{3}{*}{$\begin{array}{l}\text { Number of observations } \\
\text { Weighted\% of households }\end{array}$} & 63,578 & 6944 & 4769 & 51,865 & \\
\hline & & 15.19 (14.79-15.59) & $8.81(8.52-9.10)$ & $76.00(75.54-76.45)$ & \\
\hline & \multicolumn{4}{|c|}{ Weighted mean (95\% CI) } & \\
\hline White & $76.78(76.33-77.24)$ & $73.84(72.43-75.26)$ & $77.90(76.32-79.48)$ & $77.24(76.75-77.73)$ & 51,544 \\
\hline Black & 11.81 (11.49-12.13) & $13.64(12.59-14.68)$ & $11.90(10.73-13.07)$ & 11.43 (11.09-11.78) & 6909 \\
\hline Asian & $4.30(4.08-4.52)$ & $2.90(2.30-3.49)$ & $2.66(2.06-3.26)$ & $4.77(4.51-5.02)$ & 2151 \\
\hline Other & $7.11(6.78-7.43)$ & $9.62(8.54-10.70)$ & 7.54 (6.39-8.69) & $6.55(6.21-6.90)$ & 2974 \\
\hline Hispanic & $11.84(11.41-12.27)$ & $13.82(12.48-15.17)$ & $12.98(11.45-14.51)$ & $11.31(10.84-11.78)$ & 3988 \\
\hline Married household head & $61.77(61.29-62.25)$ & $45.58(44.11-47.05)$ & $53.74(52.00-55.49)$ & $65.94(65.43-66.45)$ & 41,314 \\
\hline Female household head only & $27.53(27.10-2.80)$ & $41.82(40.40-43.24)$ & $34.95(33.28-36.62)$ & $23.82(23.37-24.27)$ & 16,256 \\
\hline Household head's age & $52.45(52.27-52.63)$ & $49.52(48.97-50.06)$ & $53.45(52.72-54.18)$ & $52.92(52.72-53.12)$ & \\
\hline Household size & $2.56(2.55-2.58)$ & $2.82(2.77-2.87)$ & $2.77(2.71-2.82)$ & $2.49(2.47-2.51)$ & \\
\hline
\end{tabular}

Table 2. Percentage of households with a member with one or multiple health outcomes, based on IRI MedProfiler 2015 data.

\begin{tabular}{|c|c|c|c|c|c|}
\hline & All Incomes & $\begin{array}{l}\text { Household (HH) } \\
\text { Income }<=130 \% \\
\text { Poverty Income } \\
\text { Group (IG)1 }\end{array}$ & $\begin{array}{c}\text { HH Income } \\
\text { (130-185\%] Poverty } \\
\text { IG2 }\end{array}$ & $\begin{array}{l}\text { HH Income }>185 \% \\
\text { Poverty IG3 }\end{array}$ & \\
\hline $\begin{array}{l}\text { Households with a member } \\
\text { with: }\end{array}$ & \multicolumn{4}{|c|}{ Weighted percentage (95\% CI) } & 33,179 \\
\hline Type 2 diabetes (T2D) & $14.13(13.69-14.58)$ & $16.19(14.73-17.64)$ & $16.04(14.39-17.70)$ & $13.50(13.02-13.97)$ & 5945 \\
\hline Cardiovascular disease (CVD) & $42.15(41.45-42.85)$ & $39.97(37.88-42.06)$ & $44.67(42.15-47.19)$ & $42.30(41.53-43.07)$ & 16,931 \\
\hline Obesity & $21.48(20.87-22.08)$ & $26.90(24.93-28.87)$ & $23.36(21.27-25.44)$ & $20.17(19.53-20.81)$ & 7409 \\
\hline Smokes cigarettes & $16.36(15.82-16.89)$ & $27.02(25.06-28.98)$ & $22.10(20.00-24.20)$ & 13.55 (13.03-14.07) & 5587 \\
\hline T2D, CVD, and obesity & $4.47(4.22-4.72)$ & $5.92(5.08-6.75)$ & $5.53(4.56-6.50)$ & $4.05(3.79-4.32)$ & 1906 \\
\hline No T2D, CVD, or obesity & $46.60(45.85-47.34)$ & $45.01(42.75-47.27)$ & $43.28(40.66-45.91)$ & $47.30(46.49-48.12)$ & 12,939 \\
\hline
\end{tabular}

\subsection{HEI Scores by Income}

Nutrition quality of food purchases, overall and by income, is reported in Table 3. In 2015, the total HEI-2015 score of food purchased by U.S. households was 51.9 (SD 1.8) out of a possible 100. Households in IG1 had the lowest HEI-2015 score in the analysis adjusted for household size, race, and ethnicity; household head's age and marital status; and whether a household is female-led. The difference in the HEI score between the IG1 and IG2 households is 1.4 points $(p<0.001)$, while that between the IG2 and IG3 households is 3 points $(p<0.001)$.

The HEI-2015 sub-scores illustrate a similar pattern. For most sub-scores, IG3 households have the highest (better quality) scores, followed by IG2 and IG1 households, who have the lowest (poorer quality) scores. All differences are statistically significant $(p<0.001)$. The exceptions are the scores for fatty acid, refined grains, and saturated fats, where IG1 households have higher scores than IG2 households; for refined grains and saturated fats, IG2 households have higher scores than IG3 households. The only statistically insignificant difference is for the total dairy component score between IG2 and IG3 households. The largest relative difference in the sub-scores between IG1 and IG2 households as well as IG2 and IG3 households is in the whole fruit component. 
Table 3. Adjusted weighted mean Healthy Eating Index (HEI)-2015 and component scores by household income level, based on IRI Consumer Network 2015 data.

\begin{tabular}{|c|c|c|c|c|c|c|c|}
\hline \multirow[b]{2}{*}{ Measure (Max Score) } & \multirow[b]{2}{*}{ All Incomes } & \multicolumn{3}{|c|}{ Mean (Standard Deviation [Std. Dev.]) } & \multicolumn{3}{|c|}{$\begin{array}{l}\text { Statistical Significance of } \\
\text { Difference of Means between } \\
\text { Income Groups } p \text {-Value }\end{array}$} \\
\hline & & $\begin{array}{l}\text { Household (HH) } \\
\text { Income }<=130 \% \\
\text { Poverty Income } \\
\text { Group (IG)1 }\end{array}$ & $\begin{array}{l}\text { HH Income } \\
(130-185 \%] \\
\text { Poverty IG2 }\end{array}$ & $\begin{array}{c}\text { HH Income > } \\
\text { 185\% Poverty } \\
\text { IG3 }\end{array}$ & $\begin{array}{c}\text { IG1 vs. } \\
\text { IG2 }\end{array}$ & $\begin{array}{c}\text { IG1 vs. } \\
\text { IG3 }\end{array}$ & $\begin{array}{c}\text { IG2 vs. } \\
\text { IG3 }\end{array}$ \\
\hline HEI-2015 (100) & $51.86(1.84)$ & $48.24(1.10)$ & $49.56(1.07)$ & $52.57(1.13)$ & $<0.001$ & $<0.001$ & $<0.001$ \\
\hline Total vegetables (5) & $2.07(0.15)$ & $1.89(0.15)$ & $1.98(0.14)$ & $2.11(0.13)$ & $<0.001$ & $<0.001$ & $<0.001$ \\
\hline Greens and beans (5) & $1.71(0.19)$ & $1.37(0.12)$ & $1.50(0.09)$ & $1.78(0.14)$ & $<0.001$ & $<0.001$ & $<0.001$ \\
\hline Total fruits (5) & $1.59(0.16)$ & $1.27(0.08)$ & $1.45(0.10)$ & $1.65(0.11)$ & $<0.001$ & $<0.001$ & $<0.001$ \\
\hline Whole fruits (5) & $1.69(0.21)$ & $1.27(0.14)$ & $1.45(0.12)$ & $1.76(0.12)$ & $<0.001$ & $<0.001$ & $<0.001$ \\
\hline Whole grains (10) & $3.42(0.25)$ & $2.91(0.20)$ & $3.14(0.14)$ & $3.51(0.14)$ & $<0.001$ & $<0.001$ & $<0.001$ \\
\hline Total dairy (10) & $5.39(0.72)$ & $5.15(0.76)$ & $5.41(0.72)$ & $5.42(0.71)$ & $<0.001$ & $<0.001$ & 0.58 \\
\hline Total protein foods (5) & $3.09(0.15)$ & $2.90(0.12)$ & $3.00(0.16)$ & $3.12(0.14)$ & $<0.001$ & $<0.001$ & $<0.001$ \\
\hline Seafood and plant proteins (5) & $3.62(0.30)$ & $3.14(0.26)$ & $3.33(0.22)$ & $3.72(0.23)$ & $<0.001$ & $<0.001$ & $<0.001$ \\
\hline Fatty acid (10) & $4.85(0.73)$ & $5.04(0.84)$ & $4.88(0.71)$ & $4.83(0.72)$ & $<0.001$ & $<0.001$ & $<0.001$ \\
\hline Sodium (10) & $5.86(0.19)$ & $5.52(0.18)$ & $5.58(0.25)$ & $5.93(0.14)$ & $<0.001$ & $<0.001$ & $<0.001$ \\
\hline Refined grains (10) & $7.90(0.43)$ & $7.76(0.41)$ & $7.67(0.49)$ & $7.94(0.43)$ & $<0.001$ & $<0.001$ & $<0.001$ \\
\hline Saturated fat (10) & $5.77(0.63)$ & $6.04(0.76)$ & $5.84(0.65)$ & $5.73(0.59)$ & $<0.001$ & $<0.001$ & $<0.001$ \\
\hline Added sugar (10) & $4.89(0.53)$ & $3.98(0.40)$ & $4.34(0.40)$ & $5.07(0.38)$ & $<0.001$ & $<0.001$ & $<0.001$ \\
\hline
\end{tabular}

Note: Adjusted for household race and ethnicity; household head's age and marital status; and female-led household. Unadjusted measures are omitted for brevity but can be obtained from the authors upon request.

\subsection{HEI Scores by Health Condition/Behavior}

Nutrition quality of food purchases for households with and without a member with reported T2D or CVD is reported in Table 4. The HEI score is $2.4 \%(p<0.001)$ higher for households without a member with reported T2D (mean 52.4, SD 2.0) compared to households with a member with T2D (mean 51.2, SD 1.9). When comparing the difference in HEI components, the former has higher scores (better conformance with Federal recommendations) on most components $(p<0.001$ ), ranging from $0.4 \%$ (seafood and plant proteins) to $17.4 \%$ (total fruits). However, households with a member with T2D have higher scores $(p<0.001)$ for the following sub-components: refined grains (by $0.5 \%)$, total vegetables $(1.1 \%)$, total protein foods $(3.8 \%)$, fatty acid $(6.3 \%)$, and added sugar $(6.8 \%)$.

Table 4. Adjusted weighted mean HEI-2015 and component scores (standard deviations) for households with and without a member with reported T2D or CVD, based on Consumer Network (CN) 2015-MedpProfiler data.

\begin{tabular}{|c|c|c|c|c|c|c|c|c|}
\hline Measure (Max Score) & $\begin{array}{c}\text { No Type } 2 \\
\text { Diabetes }\end{array}$ & $\begin{array}{c}\text { Type } 2 \\
\text { Diabetes }\end{array}$ & $\begin{array}{c}\% \\
\text { Difference }\end{array}$ & $\begin{array}{c}\text { Difference } \\
\text { between } \\
\text { Groups } \\
p \text {-Value }\end{array}$ & No CVD & CVD & $\begin{array}{c}\% \\
\text { Difference }\end{array}$ & $\begin{array}{c}\text { Difference } \\
\text { between } \\
\text { Groups } \\
p \text {-Value }\end{array}$ \\
\hline HEI-2015 (100) & $52.41(1.98)$ & $51.19(1.89)$ & 2.38 & $<0.001$ & $52.94(2.16)$ & $51.29(1.92)$ & 3.22 & $<0.001$ \\
\hline Total vegetables (5) & $2.09(0.15)$ & $2.12(0.16)$ & -1.14 & $<0.001$ & $2.10(0.15)$ & $2.09(0.16)$ & 0.46 & $<0.001$ \\
\hline Greens and beans (5) & $1.76(0.21)$ & $1.58(0.17)$ & 11.10 & $<0.001$ & $1.80(0.22)$ & $1.64(0.18)$ & 9.39 & $<0.001$ \\
\hline Total fruits (5) & $1.62(0.16)$ & $1.38(0.21)$ & 17.40 & $<0.001$ & $1.64(0.16)$ & $1.46(0.24)$ & 12.24 & $<0.001$ \\
\hline Whole fruits (5) & $1.72(0.24)$ & $1.57(0.29)$ & 9.30 & $<0.001$ & $1.77(0.24)$ & $1.55(0.30)$ & 14.37 & $<0.001$ \\
\hline Whole grains (10) & $3.48(0.25)$ & $3.12(0.34)$ & 11.61 & $<0.001$ & $3.59(0.26)$ & $3.18(0.31)$ & 12.81 & $<0.001$ \\
\hline Total dairy (10) & $5.45(0.66)$ & $5.24(0.72)$ & 3.97 & $<0.001$ & $5.44(0.67)$ & $5.29(0.67)$ & 2.81 & $<0.001$ \\
\hline Total protein foods (5) & $3.10(0.16)$ & $3.22(0.17)$ & -3.77 & $<0.001$ & $3.14(0.17)$ & $3.09(0.16)$ & 1.63 & $<0.001$ \\
\hline $\begin{array}{l}\text { Seafood and plant } \\
\text { proteins }(5)\end{array}$ & $3.70(0.30)$ & $3.68(0.32)$ & 0.42 & $<0.001$ & $3.76(0.32)$ & $3.62(0.31)$ & 3.80 & 0.03 \\
\hline Fatty acid (10) & $4.79(0.68)$ & $5.11(0.81)$ & -6.27 & $<0.001$ & $4.81(0.69)$ & $4.94(0.72)$ & -2.66 & $<0.001$ \\
\hline Sodium (10) & $5.99(0.18)$ & $5.34(0.33)$ & 12.04 & $<0.001$ & $6.04(0.25)$ & $5.76(0.16)$ & 4.87 & $<0.001$ \\
\hline Refined grains (10) & $8.00(0.42)$ & $8.03(0.30)$ & -0.45 & $<0.001$ & $8.03(0.45)$ & $8.07(0.31)$ & -0.40 & $<0.001$ \\
\hline Saturated fat (10) & $5.77(0.57)$ & $5.48(0.76)$ & 5.31 & $<0.001$ & $5.81(0.55)$ & $5.70(0.67)$ & 1.93 & $<0.001$ \\
\hline Added sugar (10) & $4.94(0.53)$ & $5.30(0.57)$ & -6.85 & $<0.001$ & $5.03(0.52)$ & $4.91(0.58)$ & 2.35 & 0.01 \\
\hline
\end{tabular}

Adjusted for household poverty level, size, race, and ethnicity; household head's age and marital status; and female-led household. Note: Unadjusted measures are omitted for brevity but can be obtained from the authors upon request. 
Households without a member with CVD have an HEI score of 52.9 (SD 2.2), which is $3.2 \%(p<0.001)$ higher than that for households with at least one member with reported CVD (mean 51.3, SD 1.9). The former group has higher scores for 11 out of 13 components, with the difference ranging between $0.5 \%$ (total vegetables, $p<0.001$ ) and $14.4 \%$ (whole fruits, $p<0.001)$. The only HEI components for which households with a member with CVD have somewhat higher scores are refined grains (higher by $0.4 \%, p<0.001$ ) and fatty acid $(2.7 \%, p<0.001)$.

Nutrition quality of food purchases for households with and without a member with reported obesity or the three conditions (T2D, CVD, and obesity) is reported in Table 5. Households with no members with obesity have a higher HEI score $(3.3 \%$ higher, $p<0.001)$ than those with at least one member with reported obesity. In this case, too, the former group has higher scores for most HEI components than those with a member with obesity, with the difference ranging from $0.5 \%$ (seafood and plant proteins, $p<0.001$ ) to $14.1 \%$ (total fruits, $p<0.001)$. However, the scores for refined grains and total protein foods are higher for households with at least one member with reported obesity by $1.4 \%(p<0.001)$ and $2.4 \%(p<0.001)$, respectively.

Table 5. Adjusted weighted mean HEI-2015 and component scores (standard deviations) for households with and without a member with reported obesity or the three conditions (T2D, CVD, and obesity), based on CN 2015-MedpProfiler data.

\begin{tabular}{|c|c|c|c|c|c|c|c|c|}
\hline $\begin{array}{c}\text { Measure (Max } \\
\text { Score) }\end{array}$ & No Obesity & $\begin{array}{c}\text { HH with } \\
\text { Member (S) } \\
\text { with } \\
\text { Obesity }\end{array}$ & $\begin{array}{l}\% \text { Dif- } \\
\text { ference }\end{array}$ & $\begin{array}{c}\text { Difference } \\
\text { between } \\
\text { Groups } \\
p \text {-Value }\end{array}$ & $\begin{array}{l}\text { HH with } \\
\text { None of the } \\
\text { Conditions }\end{array}$ & $\begin{array}{c}\text { HH with } \\
\text { Three } \\
\text { Conditions }\end{array}$ & $\begin{array}{l}\% \text { Dif- } \\
\text { ference }\end{array}$ & $\begin{array}{c}\text { Difference } \\
\text { between } \\
\text { Groups } \\
p \text {-Value }\end{array}$ \\
\hline HEI-2015 (100) & $52.56(1.97)$ & $50.86(1.83)$ & 3.34 & $<0.001$ & $53.29(2.20)$ & $50.23(2.07)$ & 6.10 & $<0.001$ \\
\hline Total vegetables (5) & $2.10(0.15)$ & $2.08(0.14)$ & 1.00 & $<0.001$ & $2.09(0.15)$ & $2.04(0.16)$ & 2.34 & 0.02 \\
\hline Greens and beans (5) & $1.76(0.21)$ & $1.64(0.18)$ & 7.11 & $<0.001$ & $1.81(0.22)$ & $1.46(0.17)$ & 24.20 & $<0.001$ \\
\hline Total fruits (5) & $1.63(0.17)$ & $1.43(0.14)$ & 14.13 & $<0.001$ & $1.69(0.18)$ & $1.32(0.22)$ & 28.05 & $<0.001$ \\
\hline Whole fruits (5) & $1.73(0.24)$ & $1.58(0.22)$ & 9.67 & $<0.001$ & $1.80(0.24)$ & $1.52(0.26)$ & 18.90 & $<0.001$ \\
\hline Whole grains (10) & $3.50(0.25)$ & $3.14(0.27)$ & 11.48 & $<0.001$ & $3.67(0.25)$ & $2.97(0.40)$ & 23.29 & $<0.001$ \\
\hline Total dairy (10) & $5.41(0.68)$ & $5.41(0.68)$ & -0.03 & 0.003 & $5.42(0.67)$ & $5.30(0.70)$ & 2.34 & $<0.001$ \\
\hline $\begin{array}{l}\text { Total protein } \\
\text { foods (5) }\end{array}$ & $3.10(0.16)$ & $3.18(0.16)$ & -2.43 & $<0.001$ & $3.12(0.17)$ & $3.14(0.22)$ & -0.84 & $<0.001$ \\
\hline $\begin{array}{l}\text { Seafood and plant } \\
\text { proteins (5) }\end{array}$ & $3.70(0.30)$ & $3.68(0.30)$ & 0.47 & $<0.001$ & $3.76(0.31)$ & $3.58(0.32)$ & 4.99 & $<0.001$ \\
\hline Fatty acid (10) & $4.89(0.70)$ & $4.66(0.75)$ & 4.86 & $<0.001$ & $4.87(0.70)$ & $4.89(0.83)$ & -0.37 & $<0.001$ \\
\hline Sodium (10) & $5.95(0.16)$ & $5.63(0.30)$ & 5.72 & $<0.001$ & $6.11(0.25)$ & $5.33(0.44)$ & 14.64 & $<0.001$ \\
\hline Refined grains (10) & $7.97(0.40)$ & $8.09(0.40)$ & -1.43 & $<0.001$ & $8.01(0.47)$ & $8.12(0.37)$ & -1.40 & $<0.001$ \\
\hline Saturated fat (10) & $5.79(0.59)$ & $5.41(0.67)$ & 7.18 & $<0.001$ & $5.92(0.53)$ & $5.39(0.87)$ & 9.79 & $<0.001$ \\
\hline Added sugar (10) & $5.02(0.55)$ & $4.94(0.51)$ & 1.77 & $<0.001$ & $5.02(0.52)$ & $5.16(0.57)$ & -2.67 & $<0.001$ \\
\hline
\end{tabular}

Adjusted for household poverty level, size, race, and ethnicity; household head's age and marital status; and female-led household. Note: Unadjusted measures are omitted for brevity but can be obtained from the authors upon request.

Households with neither of the three health conditions have an HEI score of 53.3 (SD 2.2), which is $6.1 \%(p<0.001)$ higher than that for households with member(s) with all three conditions (mean 50.2, SD 2.1). The former group has higher scores for 9 out of 13 components, with the difference in scores ranging from $2.3 \%$ (total vegetables $(p=0.02)$ and total dairy $(p<0.001))$ to $28 \%$ (total fruits $(p<0.001)$ ). Even though households with member(s) with all three conditions score higher on four components, the difference in those sub-scores is only between $0.4 \%$ (fatty acid $(p<0.001)$ ) and $2.7 \%$ (added sugar $(p<0.001))$.

Nutrition quality of food purchases for households with and without a member reporting smoking is presented in Table 6. The difference in overall food purchase quality is the largest $(10.5 \%, p<0.001)$ between households where none of the adults reported smoking (mean HEI score of 52.9, SD 1.8) and those where at least one adult reported smoking (mean 47.9, SD 1.3). Non-smoker households score higher on all except for one component (refined grain) and the difference in sub-scores ranges from $1.5 \%$ (fatty acid $(p<0.001))$ to $59.6 \%$ (whole fruits $(p<0.001)$ ). 
Table 6. Adjusted weighted mean HEI-2015 and component scores (standard deviations) for households with and without a member reporting smoking, based on CN 2015-MedpProfiler data.

\begin{tabular}{ccccc}
\hline Measure (Max Score) & No Smoker in HH & HH with Smoker(s) & \% Difference & $\begin{array}{c}\text { Difference between } \\
\text { Groups } p \text {-Value }\end{array}$ \\
\hline HEI-2015 (100) & $52.95(1.83)$ & $47.91(1.34)$ & 10.52 & $<0.001$ \\
Total vegetables (5) & $2.11(0.16)$ & $2.01(0.13)$ & 5.25 & $<0.001$ \\
Greens and beans (5) & $1.79(0.19)$ & $1.42(0.15)$ & 26.24 & $<0.001$ \\
Total fruits (5) & $1.67(0.15)$ & $1.09(0.14)$ & 53.42 & $<0.001$ \\
Whole fruits (5) & $1.80(0.23)$ & $1.13(0.17)$ & 59.56 & $<0.001$ \\
Whole grains (10) & $3.59(0.24)$ & $2.51(0.14)$ & 43.32 & $<0.001$ \\
Total dairy (10) & $5.47(0.68)$ & $5.12(0.68)$ & 6.81 & $<0.001$ \\
Total protein foods (5) & $3.15(0.16)$ & $2.95(0.16)$ & 6.59 & $<0.001$ \\
Seafood and plant proteins (5) & $3.76(0.28)$ & $3.35(0.32)$ & 12.10 & $<0.001$ \\
Fatty acid (10) & $4.85(0.70)$ & $4.78(0.79)$ & 1.46 & $<0.001$ \\
Sodium (10) & $5.91(0.18)$ & $5.69(0.29)$ & 3.88 & $<0.001$ \\
Refined grains (10) & $7.98(0.41)$ & $8.08(0.40)$ & -1.19 & 4.14 \\
Saturated fat (10) & $5.74(0.59)$ & $5.51(0.73)$ & 19.88 & $<.002$ \\
Added sugar (10) & $5.14(0.51)$ & $4.29(0.50)$ & $<0.001$ \\
\end{tabular}

Note: Adjusted for household poverty level, size, race, and ethnicity; household head's age and marital status; and female-led household. Unadjusted measures are omitted for brevity but can be obtained from the authors upon request.

\section{Discussion}

The study analyzed the retail food purchase quality, measured in terms of HEI-2015, for a nationally representative sample of US households and compared the difference in HEI scores and component scores based on household income and reported health conditions/behavior. The findings suggest that higher-income households tend to purchase higher quality food compared to lower-income households, even though the latter score slightly higher on some of the HEI components. While higher-income households have, on average, slightly higher HEI scores, the mean HEI score of 52.6 (SD 1.1) out of 100 for households above $185 \%$ of poverty indicates a substantial need for improvement in diet quality to better conform with Federal recommendations for 13 dietary components. These general findings are consistent with evidence from previous studies based on other data sources, such as dietary recall and food frequency questionnaire data [18].

Households with at least one member reporting one of the four chronic conditions/health behaviors have statistically significantly lower HEI-2015 scores than those with no member reporting the condition(s)/behavior(s). A novel finding is that households with a member with T2D score better on the added sugar component than those with no member reporting T2D, which means that the share of purchased calories from added sugars is less for the former. Additionally, the finding that households with a member with T2D score lower on the total fruits and whole fruits components, suggesting that the share of purchased calories from those products are lower, may indicate that these households are avoiding purchasing fruits to avoid natural sugars as well. Our findings indicating lower HEI scores among households with members with chronic conditions/behaviors are consistent with previous studies. For example, using the IRI Consumer Network and MedProfiler datasets with the USDAScore [23] or fruit and vegetable share of food purchases [24] as a measures of food purchase quality, it has been shown that high food purchase quality is negatively associated with obesity status/incidence of obesity. In contrast, using the same datasets and Healthshare score as a measure of food purchase quality, one study [25] found that those with T2D have a higher household food purchase quality than those without T2D.

While food purchases do not necessarily fully translate into food intake, our findings are also consistent with studies analyzing the association between diet quality and chronic diseases. Past studies have found that higher-quality diets are associated with lower incidence and odds of obesity $[23,24]$ and that smokers have lower HEIs than non-smokers [26]. Systematic reviews and meta-analyses [6,27] of cohort studies on health outcomes and diet quality measured in terms of HEI, Alternative HEI (AHEI), and Dietary Approaches to Stop 
Hypertension (DASH) scores found that higher diet quality is associated with significant risk reduction for all-cause mortality, CVD, cancer, T2D, and neurodegenerative diseases.

\section{Contributions and Limitations}

This study complements the existing literature in two major ways. First, most studies analyzing the association between HEI scores and health outcomes have relied on selfreported 24-h dietary recall data $[6,8,9,27]$ and food frequency questionnaire data [10-16]. Major limitations of constructing HEI scores based on these data are that scores based on one or a few days of food intake do not necessarily reflect usual individual diet (24-h recall data) and there are systematic biases (food frequency data), due in part to not capturing the entire diet and the difficulty of the recall task [2]. In contrast, this study focuses on retail food purchases over an entire year, which provides a more comprehensive view of household at-home food environments and potentially contains less bias. Second, this study includes multiple health conditions/behaviors individually and combined, whereas past studies, to our knowledge, have primarily focused on one or two conditions at a time regardless of the type of utilized data $[6,23-25,27]$.

Our study comes with several limitations. First, our measures of food quality are based solely on food-at-home purchase data, thus omitting the impact of food-awayfrom-home on diet and the potential associations with household income and health outcomes/behaviors. According to ERS, the normalized food-at-home expenditure by households as a percentage of total food expenditure (food-at-home and food-away-fromhome) was 53\% in 2015 [28]. Second, given that we use food scanner data, we can only measure the healthfulness of food purchases but not consumption. Even though food purchase does not fully capture food intake [29], it is a proxy of the healthfulness of the home food environments [30]. Third, due to the structure of the data, our measure of food purchase quality and health outcomes/behaviors are at the household-level. Therefore, we are unable to capture individual-level differences and variations, although home food environments do shape the individual dietary intake $[19,31]$. Fourth, our analysis only focuses on those households participating in both datasets (CNP and MedProfiler). This represents just under half of the static CNP, but the statistical properties, such as comparisons to government-collected data, have not been evaluated [20]. Fifth, the panel HEI scores might be lower because fruits, vegetables, eggs, and seafood tend to be under reported compared to government expenditure surveys. Additionally, since we do not know the quantities of the random-weight fruit and vegetable purchases, about half of the expenditures on produce is omitted from the analysis. However, the impact of excluded randomweight products on HEI is unknown because different product categories (i.e., fresh meat, poultry, seafood, bakery, fruits, vegetables, cheese, cold cuts and lunch meat, prepared foods, coffee, and candy, nuts, and seeds) affect the HEI differently. Lastly, the health outcomes/behaviors are self-reported, meaning that some respondents may not have diagnosed/be aware of their health conditions at the time of reporting, thus being categorized as non-T2D/CVD/obesity households in this study.

\section{Conclusions}

Given that the average food purchase quality is lower than the recommended levels, especially for those with diet-related chronic diseases, the findings from this study suggest the need for greater efforts to promote healthier food purchases among Americans. Strategies identified as effective in systematic reviews [32,33], such as pricing interventions, advertising/promoting healthier food items, monetary nudges, and nutrition counseling, could be implemented to improve food purchase quality and subsequent diet-related chronic conditions.

Author Contributions: Conceptualization, K.R. and A.C.; methodology, A.G., A.C. and K.R.; software, A.G. and A.C.; validation, A.C.; formal analysis, A.G. and A.C.; resources, A.C. and A.Y.R.; data curation, A.G., A.C. and A.Y.R.; writing-original draft preparation, A.G.; writing-review and editing, K.R., A.C., A.Y.R. and A.G.; visualization, A.G., K.R. and A.C.; supervision, K.R. and A.C.; 
project administration, K.R. and A.C. All authors have read and agreed to the published version of the manuscript.

Funding: This research received no external funding.

Institutional Review Board Statement: Not applicable.

Informed Consent Statement: Not applicable.

Data Availability Statement: Not applicable.

Conflicts of Interest: The authors declare no conflict of interest.

CDC Disclaimer: The findings and conclusions in this article are those of the authors and do not necessarily represent the official position of CDC.

USDA/IRI Disclaimer: The findings and conclusions in this study are those of the authors and should not be construed to represent any official USDA or U.S. Government determination or policy. The analyses, findings, and conclusions expressed in this study also should not be attributed to Information Resources, Inc. (IRI).

\section{References}

1. Mozaffarian, D. Dietary and policy priorities for cardiovascular disease, diabetes, and obesity: A comprehensive review. Circulation 2016, 133, 187-225. [CrossRef]

2. Kirkpatrick, S.I.; Reedy, J.; Krebs-Smith, S.M.; Pannucci, T.E.; Subar, A.F.; Wilson, M.M.; Lerman, J.; Tooze, J.A. Applications of the Healthy Eating Index for surveillance, epidemiology, and intervention research: Considerations and caveats. J. Acad. Nutr. Diet. 2018, 118, 1603-1621. [CrossRef] [PubMed]

3. Hu, E.A.; Steffen, L.M.; Coresh, J.; Appel, L.J.; Rebholz, C.M. Adherence to the Healthy Eating Index-2015 and Other Dietary Patterns May Reduce Risk of Cardiovascular Disease, Cardiovascular Mortality, and All-Cause Mortality. J. Nutr. 2020, 150, 312-321. [CrossRef]

4. Dietary Guidelines Advisory Committee. Scientific Report of the 2020 Dietary Guidelines Advisory Committee: Advisory Report to the Secretary of Agriculture and the Secretary of Health and Human Services; US Department of Agriculture: Washington, DC, USA, 2020.

5. Dietary Guidelines Advisory Committee. Dietary Guidelines for Americans 2015-2020, 8th ed.; U.S. Department of Health Human Services: Washington, DC, USA, 2015.

6. Schwingshackl, L.; Bogensberger, B.; Hoffmann, G. Diet quality as assessed by the healthy eating index, alternate healthy eating index, dietary approaches to stop hypertension score, and health outcomes: An updated systematic review and meta-analysis of cohort studies. J. Acad. Nutr. Diet. 2018, 118, 74-100.e11. [CrossRef] [PubMed]

7. Morze, J.; Danielewicz, A.; Hoffmann, G.; Schwingshackl, L. Diet Quality as Assessed by the Healthy Eating Index, Alternate Healthy Eating Index, Dietary Approaches to Stop Hypertension Score, and Health Outcomes: A Second Update of a Systematic Review and Meta-Analysis of Cohort Studies. J. Acad. Nutr. Diet. 2020, 120, 1998-2031. [CrossRef]

8. Orr, C.J.; Keyserling, T.C.; Ammerman, A.S.; Berkowitz, S.A. Diet quality trends among adults with diabetes by socioeconomic status in the US: 1999-2014. BMC Endocr. Disord. 2019, 19, 54. [CrossRef]

9. Park, Y.-M.M.; Fung, T.T.; Steck, S.E.; Zhang, J.; Hazlett, L.J.; Han, K.; Lee, S.-H.; Merchant, A.T. Diet Quality and Mortality Risk in Metabolically Obese Normal-Weight Adults. Mayo Clin. Proc. 2016, 91, 1372-1383. [CrossRef]

10. Cespedes, E.M.; Hu, F.B.; Tinker, L.; Rosner, B.; Redline, S.; Garcia, L.; Hingle, M.; van Horn, L.; Howard, B.V.; Levitan, E.B.; et al. Multiple healthful dietary patterns and type 2 diabetes in the Women's Health Initiative. Am. J. Epidemiol. 2016, 183, 622-633. [CrossRef] [PubMed]

11. George, S.M.; Ballard-Barbash, R.; Manson, J.E.; Reedy, J.; Shikany, J.M.; Subar, A.F.; Tinker, L.F.; Vitolins, M.; Neuhouser, M.L. Comparing indices of diet quality with chronic disease mortality risk in postmenopausal women in the Women's Health Initiative Observational Study: Evidence to inform national dietary guidance. Am. J. Epidemiol. 2014, 180, 616-625. [CrossRef]

12. Harmon, E.B.; Boushey, C.J.; Shvetsov, Y.B.; Ettienne, R.; Reedy, J.; Wilkens, L.R.; Le Marchand, L.; Henderson, B.E.; Kolonel, L.N. Associations of key diet-quality indexes with mortality in the Multiethnic Cohort: The Dietary Patterns Methods Project. Am. J. Clin. Nutr. 2015, 101, 587-597. [CrossRef]

13. Jacobs, S.; Harmon, B.E.; Boushey, C.J.; Morimoto, Y.; Wilkens, L.R.; Le Marchand, L.; Kröger, J.; Schulze, M.B.; Kolonel, L.N.; Maskarinec, G. A priori-defined diet quality indexes and risk of type 2 diabetes: The Multiethnic Cohort. Diabetologia 2015, 58, 98-112. [CrossRef]

14. Yu, D.; Sonderman, J.; Buchowski, M.; McLaughlin, J.K.; Shu, X.-O.; Steinwandel, M.; Signorello, L.B.; Zhang, X.; Hargreaves, M.K.; Blot, W.J.; et al. Healthy eating and risks of total and cause-specific death among low-income populations of African-Americans and other adults in the southeastern United States: A prospective cohort study. PLoS Med. 2015, 12, e1001830. [CrossRef] [PubMed] 
15. Conway, B.N.; Han, X.; Munro, H.M.; Gross, A.L.; Shu, X.-O.; Hargreaves, M.K.; Zheng, W.; Powers, A.C.; Blot, W.J. The obesity epidemic and rising diabetes incidence in a low-income racially diverse southern US cohort. PLoS ONE 2018, 13, e0190993. [CrossRef] [PubMed]

16. Panizza, C.E.; Shvetsov, Y.B.; Harmon, B.E.; Wilkens, L.R.; Le Marchand, L.; Haiman, C.; Reedy, J.; Boushey, C.J. Testing the predictive validity of the healthy eating index-2015 in the multiethnic cohort: Is the score associated with a reduced risk of all-cause and cause-specific mortality? Nutrients 2018, 10, 452. [CrossRef] [PubMed]

17. Carlson, A.C.; Page, E.T.; Zimmerman, T.P.; Tornow, C.E.; Hermansen, S. Linking USDA Nutrition Databases to IRI Household-Based and Store-Based Scanner Data; Technical Bulletin Number 1952; Economic Research Service, U.S. Department of Agriculture: Washington, DC, USA, 2019.

18. French, S.A.; Tangney, C.C.; Crane, M.; Wang, Y.; Appelhans, B.M. Nutrition quality of food purchases varies by household income: The SHoPPER study. BMC Public Health 2019, 19, 231. [CrossRef]

19. Mancino, L.; Guthrie, J.; Ver Ploeg, M.; Lin, B.-H. Nutritional Quality of Foods Acquired by Americans: Findings from USDA's National Household Food Acquisition and Purchase Survey; Economic Information Bulletin Number 188; Economic Research Service, U.S. Department of Agriculture: Washington, DC, USA, 2018.

20. Muth, M.K.; Sweitzer, M.; Brown, D.; Capogrossi, K.; Karns, S.; Levin, D.; Okrent, A.; Siegel, P.; Zhen, C. Understanding IRI Household-Based and Store-Based Scanner Data; Technical Bulletin Number 1942; Economic Research Service, U.S. Department of Agriculture: Washington, DC, USA, 2016.

21. Sweitzer, M.; Brown, D.; Karns, S.; Muth, M.K.; Siegel, P.; Zhen, C. Food-at-Home Expenditures: Comparing Commercial Household Scanner Data from IRI and Government Survey Data; Technical Bulletin Number 1946; Economic Research Service, U.S. Department of Agriculture: Washington, DC, USA, 2017.

22. US Department of Health Human Services. Poverty Guidelines. US Federal Poverty Guidelines Used to Determine Financial Eligibility for Certain Federal Programs. 2015. Available online: https:/ /aspe.hhs.gov/2015-poverty-guidelines (accessed on 20 October 2020).

23. Chen, D.; Jaenicke, E.C.; Volpe, R.J. Food environments and obesity: Household diet expenditure versus food deserts. Am. J. Public Health 2016, 106, 881-888. [CrossRef] [PubMed]

24. Volpe, R.; Cai, X.; Schroeter, C.; Mancino, L. The Effect of Produce Purchasing Behavior on Adult Obesity and Body Weight: Evidence from Household-Level Scanner Data. Agric. Resour. Econ. Rev. 2019, 48, 253-273. [CrossRef]

25. Adjemian, M.; Volpe, R.J.; Adjemian, J. Relationships between diet, alcohol preference, and heart disease and type 2 diabetes among Americans. PLoS ONE. 2015, 10, e0124351. [CrossRef]

26. Reedy, J.; Lerman, J.; Krebs-Smith, S.M.; Kirkpatrick, S.I.; Pannucci, T.; Wilson, M.M.; Subar, A.F.; Kahle, L.L.; Tooze, J.A. Evaluation of the healthy eating index-2015. J. Acad. Nutr. Diet. 2018, 118, 1622-1633. [CrossRef]

27. Schwingshackl, L.; Hoffmann, G. Diet quality as assessed by the Healthy Eating Index, the Alternate Healthy Eating Index, the Dietary Approaches to Stop Hypertension score, and health outcomes: A systematic review and meta-analysis of cohort studies. J. Acad. Nutr. Diet. 2015, 115, 780-800. [CrossRef]

28. Zeballos, E.; Sinclair, W. Normalized Food Expenditures by All Purchasers and Household Final Users; Food Expenditure Series; Economic Research Service, U.S. Department of Agriculture: Washington, DC, USA, 2020.

29. Appelhans, B.M.; French, S.A.; Tangney, C.C.; Powell, L.M.; Wang, Y. To what extent do food purchases reflect shoppers' diet quality and nutrient intake? Int. J. Behav. Nutr. Phys. Act. 2017, 14, 46. [CrossRef] [PubMed]

30. Vadiveloo, M.; Perraud, E.; Parker, H.W.; Juul, F.; Parekh, N. Geographic Differences in the Dietary Quality of Food Purchases among Participants in the Nationally Representative Food Acquisition and Purchase Survey (FoodAPS). Nutrients 2019, 11, 1233. [CrossRef] [PubMed]

31. Frazao, E.; Andrews, M.; Smallwood, D.; Prell, M. Food Spending Patterns of Low-Income Households: Will Increasing Purchasing Power Result in Healthier Food Choices? Can Food Stamps Do More to Improve Food Choices? An Economic Perspective; Economic Information Bulletin Number 29-4; United States Department of Agriculture: Washington, DC, USA, 2007.

32. Liberato, S.C.; Bailie, R.; Brimblecombe, J. Nutrition interventions at point-of-sale to encourage healthier food purchasing: A systematic review. BMC Public Health 2014, 14, 919. [CrossRef] [PubMed]

33. Escaron, A.L.; Meinen, A.M.; Nitzke, S.A.; Martinez-Donate, A.P. Peer reviewed: Supermarket and grocery store-based interventions to promote healthful food choices and eating practices: A systematic review. Prev. Chronic Dis. 2013, 10, E50. [CrossRef] 